\title{
54. THE CHEMISTRY OF ALTERED BASALTS AT SITE 417, DEEP SEA DRILLING PROJECT LEG 51 ${ }^{1}$
}

\author{
Thomas W. Donnelly, Department of Geological Sciences, State University of New York, Binghamton, New York \\ Geoffrey Thompson, Department of Chemistry, Woods Hole Oceanographic Institution, Woods Hole, Massachusetts \\ and \\ Matthew H. Salisbury, Deep Sea Drilling Project and Geological Research Division, \\ Scripps Institution of Oceanography, La Jolla, California
}

\begin{abstract}
A chemical study of 200 meters of highly altered basalt from Hole $417 \mathrm{~A}$ shows that potassium is strikingly enriched in these rocks, and that calcium, magnesium, and sodium are all depleted. Manganese is very slightly depleted and phosphorus slightly enriched. A comparison of these rocks with fresher examples from nearby Hole 417D suggests that they were originally the same materials. Silicon, titanium, total iron, and aluminum cannot be shown to have moved during alteration; a small difference in estimated original aluminum composition is explained on the basis of original variation in plagioclase content. Of the minor elements, lithium, boron, and barium are strongly enriched, and none of the elements can be shown to be generally depleted, although several (yttrium, strontium, nickel) are slightly redistributed during alteration.

A calculation of the budget of alteration shows that about 690 grams of potassium have been introduced for a 200 -meter column of rock that is $1 \mathrm{~cm}^{2}$ in cross-section. Because hydrogen ion is needed to maintain electrical balance, bicarbonate is probably consumed, yielding carbonate ion. If sea water is the altering fluid, then differing assumptions as to the original porosity show that an amount equal to 700 to 1600 volumes of the original void space must have been supplied, if potassium is the limiting chemical species and if it is completely removed from the water. Assuming a low temperature of alteration (on the basis of mineralogy and oxygen isotopes), the amount of heat necessary to drive the required volume of water through the rock must come from a crustal section in excess of what was drilled.
\end{abstract}

\section{INTRODUCTION}

The drilling of 200 meters of highly altered basalt and the recovery of about two-thirds of this basalt have provided us with an unparalleled opportunity to study the effects of alteration of oceanic basalts. Numerous observations have been made in the past based principally on dredged pillow basalts (Hart, 1970; Matthews, 1971; Thompson, 1973; Scott and Hajash, 1976; Humphris and Thompson, 1978); the applicability of the chemical and mineralogical conclusions of these studies is somewhat diminished by the difficulty of reconstructing the original spatial relationships of the dredged rocks, by the possibility that samples dredged from scarps might represent local alteration processes along fissures, and by the difficulty of calculating chemical fluxes. A further problem is that rocks exposed for very long times directly to sea water may have undergone an alteration which is completely atypical for the crust as a whole.

\footnotetext{
'Woods Hole Oceanographic Institution Contribution Number 4146.
}

\section{LEG 51 RESULTS}

During Leg 51, two holes were drilled about 450 meters apart. Basalt was encountered 130 meters shallower in Hole 417A than in Hole 417D; the absence of the lower portion of the sedimentary section in Hole 417A suggests that this site represents an original topographic high which was free of sediment for approximately 20 million years, a conclusion reinforced by the strikingly higher degree of alteration visible in the basalts of the shallower hole.

The basalt at Hole 417A is gray-brown to brown, especially in the more altered portions, while the basalt at Hole $417 \mathrm{D}$ is gray. The mineral content and chemical composition in Hole 417D vary little with depth. Fresh glass is widespread in this hole, and although there are chemical and mineralogical signs of erratic alteration (higher $\mathrm{K}_{2} \mathrm{O}$, oxidation of iron), the phenocrysts are commonly very fresh and the basalt as a whole also would be characterized as very fresh. The basalt in Hole $417 \mathrm{~A}$, on the other hand, is so altered that inferences about its original composition would be very difficult to draw if this hole had been the only one drilled. However, the phenocryst content is fairly uniform 
and was originally similar to that at Hole 417D (they are now extensively replaced), leading to the view that the original rock compositions were probably very similar. Also, one lithologic unit (the massive, ophitic basalt of Unit 18), and portions of the thick flows of Unit 16 are fairly fresh, based on $\mathrm{K}_{2} \mathrm{O}$ content and the oxidation state of the iron. These are similar to the fresher basalts at Hole 417D, leading again to the conclusion that the original basalt at Hole $417 \mathrm{~A}$ was probably essentially the same as that at $417 \mathrm{D}$. However, this basalt is a plagioclase-phyric, low- $\mathrm{Ti}$, low-Mg basalt, and we cannot rule out the possibility that the original distribution of $\mathrm{Al}$ in these basalts is erratic.

The two sections are not obviously correlative in detail. In Hole $417 \mathrm{~A}$, there is a high content of hyaloclastite and a distinctive, coarse-grained, ophitic massive basalt near the base of the drilled section. In Hole 417D, there is far less hyaloclastite and, although a massive basalt is present, it is finer grained and appears at a different horizon. That the sections might be separated by a post-extrusive fault is suggested by a brecciated interval separating units with differing paleomagnetic inclinations in Hole 417D. However, whether or not such a fault exists, and regardless of whether there was rotation of the basalt in Hole 417D, we conclude that direct correlation of the sections in the two holes cannot be made and suggest that the shallower Hole 417A represents an original accumulation of flows and hyaloclastites which formed a topographic high on the sea floor.

The mineralogy of the basalts at Hole 417A is discussed elsewhere. Basically, however, they are plagioclase-phyric with minor olivine and (especially lower in the section) clinopyroxene phenocrysts. The mineralogy is dominantly secondary, with the phenocrysts replaced by carbonate, smectite, and zeolites, and with widespread K-feldspar both in the groundmass and after plagioclase. The groundmass is altered to hydrated iron oxides, smectite, calcite, celadonite, and zeolites (including widespread analcime, natrolite, and phillipsite; local chabazite; and other unidentified zeolites). There is no consistent mineral zonation with depth, but the more thoroughly altered basalts occur at shallower depths.

The mineralogy of the altered basalts is consistent with very low temperatures of alteration. Analcime and $\mathrm{K}$-feldspar are widespread authigenic minerals, the latter especially in oceanic sediments. The opaque minerals (Plasse, this volume) show no textural evidence of high-temperature alteration, although they have been extensively oxidized. Oxygen isotopic evidence (Muehlenbachs; this volume) similarly indicate alteration at low temperatures, though slightly above that of abyssal sea water.

The abundance of highly altered basalt at shallow depths in the basement might suggest that alteration was caused by downward penetration of sea water. The slightly higher temperatures shown by oxygen isotopes, however, argue against downward penetration at this site and suggest that the water may have penetrated the basalt section elsewhere and at this hole was migrating upward from greater depth. The extent of alteration is not simply related to depth, but appears to be more closely related to original textural and structural variations in the basalt. Thus, the abundance of hyaloclastite and the thinness of the pillow basalt units in the higher portion of the hole may be more important in explaining the more intense alteration here. Two wellrecovered units near the bottom of the hole (lithologic Units 16 and 18) are, respectively, a series of four thick pillow basalt flows with very large pillows, and a massive coarsegrained basalt which could be either a shallow sill or a ponded flow. Both units have minimal fracturing and minimal alteration. However, the lowest unit in Hole 417A is a highly altered basalt breccia. While drilling this unit, the untimely failure of the Glomar Challenger's bow thruster prevented us from finding what degree of alteration exists at still greater depths.

\section{SAMPLE SELECTION AND TECHNIQUES}

The results reported here are a combination of the shipboard X-ray fluorescence results (which do not include $\mathrm{Mn}, \mathrm{Na}, \mathrm{P}$, or ferrous $\mathrm{Fe}$ ) and our own chemical analyses. The former rocks were selected largely for their "fresh" appearance and are probably biased against alteration. Our own selection was more general, but included several rocks which were more altered. Three rock types were recognized: hyaloclastite, which has a fairly homogeneous chemical composition; altered or "red-brown"' basalt, which represents the more typical basalt. For calculation of the budgets of alteration, the red-brown basalt analyses were omitted; they are volumetrically insignificant and of value chiefly for demonstrating chemical trends.

Each sample was fused in a lithium borate mixture and then dissolved in acids. $\mathrm{Si}, \mathrm{Al}, \mathrm{Ti}$, and $\mathrm{P}$ were determined by colorimetric means, and $\mathrm{Fe}, \mathrm{Mn}, \mathrm{Mg}, \mathrm{Ca}, \mathrm{Na}$, and $\mathrm{K}$ by atomic absorption; determinations of major element chemical composition of Hole 417A and 417D samples is presented in Table 1. Ferrous iron was determined by the standard method which consists of decomposition by boiling in a mixture of $\mathrm{HF}$ and $\mathrm{H}_{2} \mathrm{SO}_{4}$, followed by a titration with potassium dichromate using sodium diphenylamine sulfonate as an indicator. Water was determined by weighing the thermally evolved water generated by a sodium tungstate flux. Water-soluble chloride was determined using a mercuric nitrate titration, and the values of $\mathrm{Na}$ were corrected for sea water. The corrections were very small. The accuracy of these techniques has been reported elsewhere (Donnelly et al., 1973; Donnelly and Wallace, 1976).

Minor element analyses of a selected subset of the samples were made by direct-reading emission spectroscopy. The accuracy of these determinations is approximately 10 per cent of the amount found (Thompson and Bankston, 1969).

\section{RESULTS}

\section{Potassium}

The potassium values of the shallower, more altered samples are the highest ever recorded for oceanic basalts and exceed, in one case, 9 weight per cent on a water-free basis. The highest values are for the most severely altered basalt ("red-brown") and for basalt breccia fragments in dominantly hyaloclastic units. The lowest values are from the centers of the larger pillows in the lower units (such as 
TABLE 1

Major Element Chemical Composition of Samples From Holes 417A and 417D

\begin{tabular}{|c|c|c|c|c|c|c|c|c|c|c|c|}
\hline $\begin{array}{c}\text { Sample } \\
\text { (Interval in } \mathrm{cm} \text { ) }\end{array}$ & $\begin{array}{l}\text { Lithologic } \\
\text { Unit }\end{array}$ & $\mathrm{SiO}_{2}$ & $\mathrm{TiO}_{2}$ & $\mathrm{Al}_{2} \mathrm{O}_{3}$ & $\mathrm{Fe}_{2} \mathrm{O}_{3}$ & $\mathrm{FeO}$ & $\mathrm{MnO}$ & $\mathrm{MgO}$ & $\mathrm{CaO}$ & $\mathrm{Na}_{2} \mathrm{O}$ & $\mathrm{K}_{2} \mathrm{O}$ \\
\hline Hole 417A & & & & & & & & & & & \\
\hline $24-2,4$ & $2 \mathrm{~A}$ & 45.8 & 1.87 & 15.7 & 15.4 & 0.20 & 0.18 & 3.20 & 1.62 & 1.00 & 5.80 \\
\hline $24-2,37$ & $2 \mathrm{~A}$ & 50.3 & 1.71 & 19.1 & 9.52 & 0.60 & 0.14 & 3.03 & 3.22 & 1.68 & 5.32 \\
\hline $24-2,58$ & $2 \mathrm{~A}$ & 47.5 & 1.19 & 15.4 & 10.7 & 0.10 & 0.55 & 3.09 & 4.10 & 1.30 & 3.86 \\
\hline $24-2,58$ & $2 \mathrm{~A}$ & 42.4 & 2.16 & 15.8 & 18.0 & 0.20 & 0.16 & 1.92 & 0.93 & 0.75 & 7.33 \\
\hline $25-1,57$ & $2 B$ & 49.8 & 1.48 & 17.9 & 6.63 & 2.64 & 0.18 & 5.28 & 7.24 & 1.85 & 3.56 \\
\hline $26 \cdot 1,31$ & 2B & 48.2 & 1.86 & 17.6 & 13.0 & 0.40 & 0.16 & 2.94 & 2.94 & 1.77 & 6.07 \\
\hline $26-1,39$ & 2B & 47.7 & 1.53 & 18.1 & 8.81 & 2.02 & 0.16 & 5.17 & 7.57 & 2.09 & 2.70 \\
\hline $26-2,10$ & $3 \mathrm{~B}$ & 48.2 & 1.46 & 17.3 & 7.23 & 3.76 & 0.22 & 6.37 & 9.42 & 2.21 & 1.36 \\
\hline $26-3,86$ & 4 & 44.4 & 1.66 & 16.6 & 10.1 & 1.16 & 0.10 & 4.60 & 6.12 & 1.38 & 5.36 \\
\hline $26-4,103$ & 4 & 48.4 & 1.01 & 15.0 & 10.3 & 0.40 & 0.06 & 5.52 & 2.58 & 1.40 & 3.69 \\
\hline $26-5,72$ & 4 & 45.2 & 2.00 & 18.0 & 11.8 & 0.73 & 0.12 & 4.56 & 3.42 & 1.73 & 5.14 \\
\hline $26-5,72$ & 4 & 48.9 & 0.83 & 15.6 & 11.6 & 0.71 & 0.08 & 8.60 & 1.07 & 1.61 & 3.19 \\
\hline $27-2,15$ & 5 & 46.8 & 1.47 & 17.4 & 7.81 & 3.02 & 0.16 & 5.47 & 8.96 & 2.17 & 1.83 \\
\hline $28-1,36$ & $6 \mathrm{~A}$ & 45.5 & 2.18 & 15.8 & 14.8 & 0.48 & 0.08 & 3.92 & 0.90 & 0.72 & 8.12 \\
\hline $28-1,36$ & $6 \mathrm{~A}$ & 50.1 & 1.91 & 15.4 & 8.97 & 1.01 & 0.10 & 4.70 & 2.57 & 0.64 & 8.91 \\
\hline $28-1,36$ & $6 \mathrm{~A}$ & 51.8 & 0.89 & 17.5 & 8.80 & 0.39 & 0.08 & 6.08 & 1.11 & 1.49 & 4.96 \\
\hline $28-2,131$ & 7 & 49.3 & 1.58 & 18.7 & 9.00 & 1.54 & 0.12 & 5.09 & 6.59 & 2.04 & 3.43 \\
\hline $28-2,131$ & 7 & 49.1 & 1.05 & 17.1 & 9.62 & 0.46 & 0.08 & 5.34 & 3.70 & 1.34 & 4.15 \\
\hline $28-3,119$ & 8 & 48.9 & 1.45 & 17.9 & 7.34 & 3.28 & 0.14 & 5.88 & 7.81 & 2.37 & 1.79 \\
\hline $29-1,86$ & 8 & 45.4 & 1.10 & 18.0 & 4.24 & 3.36 & 0.16 & 6.62 & 13.6 & 2.15 & 0.45 \\
\hline $29-3,132$ & 8 & 46.8 & 1.40 & 17.3 & 6.22 & 3.36 & 0.16 & 5.82 & 12.3 & 2.09 & 0.79 \\
\hline $29-5,37$ & 8 & 46.6 & 1.39 & 17.7 & 7.37 & 3.72 & 0.16 & 5.71 & 10.2 & 2.30 & 1.09 \\
\hline $29-5.37$ & 8 & 44.1 & 0.93 & 15.5 & 8.35 & 0.36 & 0.06 & 4.41 & 8.13 & 1.29 & 3.30 \\
\hline $30-1,55$ & 9 & 49.0 & 1.38 & 17.7 & 7.23 & 2.98 & 0.14 & 5.43 & 9.97 & 2.36 & 1.46 \\
\hline $30-3,106$ & 10 & 48.4 & 1.81 & 16.6 & 9.90 & 3.20 & 0.14 & 4.56 & 7.66 & 2.32 & 2.54 \\
\hline $30-5,24$ & 11 & 48.5 & 1.91 & 17.2 & 11.2 & 1.72 & 0.10 & 3.15 & 6.36 & 3.05 & 3.66 \\
\hline $30-5,24$ & 11 & 51.5 & 1.31 & 17.9 & 10.7 & 0.38 & 0.08 & 4.10 & 1.94 & 1.38 & 4.31 \\
\hline $31-1,38$ & 11 & 48.0 & 1.48 & 17.3 & 9.02 & 2.12 & 0.14 & 5.14 & 7.02 & 2.02 & 2.96 \\
\hline $31-2,117$ & 11 & 46.4 & 2.20 & 16.8 & 11.0 & 2.36 & 0.14 & 5.32 & 5.86 & 1.51 & 3.18 \\
\hline $31-3,102$ & 12 & 48.5 & 1.21 & 19.4 & 7.06 & 2.78 & 0.16 & 5.46 & 7.78 & 2.41 & 1.42 \\
\hline $33-1,106$ & 13 & 45.2 & 1.38 & 17.0 & 5.77 & 3.30 & 0.16 & 5.80 & 12.7 & 2.44 & 0.99 \\
\hline $34-5,37$ & 14 & 45.6 & 1.40 & 17.9 & 6.35 & 3.00 & 0.16 & 5.89 & 11.1 & 2.50 & 0.73 \\
\hline $34-6,143$ & 15 & 48.2 & 1.87 & 18.1 & 10.0 & 1.82 & 0.10 & 4.61 & 6.14 & 2.57 & 2.80 \\
\hline $36-2,95$ & $16 \mathrm{~A}$ & 42.3 & 1.25 & 16.7 & 7.27 & 4.00 & 0.20 & 5.76 & 13.2 & 2.13 & 0.65 \\
\hline $36 \cdot 3,32$ & $16 \mathrm{~A}$ & 47.2 & 1.40 & 18.3 & 6.86 & 3.28 & 0.16 & 5.00 & 12.1 & 2.34 & 1.16 \\
\hline $38-3,70$ & $16 \mathrm{~A}$ & 47.8 & 1.52 & 17.1 & 4.45 & 5.40 & 0.17 & 6.18 & 12.8 & 2.39 & 0.04 \\
\hline $38-6,76$ & $16 \mathrm{~B}$ & 43.0 & 1.54 & 17.5 & 9.59 & 2.12 & 0.12 & 3.63 & 10.2 & 2.85 & 1.42 \\
\hline $40-2,130$ & $16 \mathrm{C}$ & 49.1 & 1.44 & 18.2 & 4.36 & 4.18 & 0.18 & 6.41 & 12.7 & 2.29 & 0.12 \\
\hline $42-1,110$ & $16 \mathrm{D}$ & 46.9 & 1.64 & 19.2 & 11.7 & 1.27 & 0.10 & 2.47 & 10.2 & 2.30 & 1.11 \\
\hline $42-1,124$ & $16 \mathrm{D}$ & 48.2 & 1.58 & 16.8 & 7.01 & 4.23 & 0.12 & 4.38 & 13.3 & 2.21 & 0.55 \\
\hline $42-4,118$ & $16 \mathrm{D}$ & 47.2 & 1.49 & 17.7 & 8.72 & 2.90 & 0.06 & 3.15 & 12.5 & 2.11 & 1.25 \\
\hline $43-5,8$ & $18 \mathrm{~A}$ & 49.8 & 1.50 & 16.8 & 2.99 & 7.12 & 0.12 & 6.44 & 12.2 & 2.10 & 0.08 \\
\hline $43-5,8$ & $18 \mathrm{~A}$ & 49.4 & 1.40 & 16.0 & 3.67 & 6.60 & 0.18 & 6.56 & 12.9 & 2.19 & 0.06 \\
\hline $44-2,8$ & $18 \mathrm{~B}$ & 48.1 & 1.46 & 17.2 & 4.04 & 6.70 & 0.14 & 6.48 & 11.8 & 1.75 & 0.08 \\
\hline $44-2,8$ & & 49.1 & 1.40 & 16.7 & 3.65 & 6.74 & 0.17 & 6.68 & 12.4 & 2.17 & 0.08 \\
\hline $44-3,58$ & $18 \mathrm{~B}$ & 49.8 & 1.49 & 16.7 & 3.51 & 6.74 & 0.16 & 6.76 & 12.4 & 2.16 & 0.10 \\
\hline $44-4,5$ & $18 \mathrm{~B}$ & 49.5 & 1.53 & 16.6 & 4.37 & 6.38 & 0.16 & 6.96 & 12.0 & 2.29 & 0.06 \\
\hline $44-4,5$ & & 50.3 & 1.41 & 16.0 & 3.79 & 6.33 & 0.16 & 7.37 & 12.9 & 2.10 & 0.08 \\
\hline $46-1,23$ & $18 \mathrm{~B}$ & 47.8 & 1.33 & 15.3 & 3.36 & 6.92 & 0.18 & 9.41 & 12.0 & 2.00 & 0.12 \\
\hline $46-2,4$ & 19 & 47.9 & 1.69 & 18.2 & 2.36 & 7.93 & 0.12 & 5.18 & 7.04 & 3.28 & 0.41 \\
\hline $46-2,44$ & 19 & 47.4 & 1.43 & 16.5 & 1.74 & 9.88 & 0.08 & 3.62 & 6.21 & 3.64 & 2.63 \\
\hline $46 \cdot 3,17$ & 19 & 46.8 & 1.57 & 18.7 & 2.52 & 7.36 & 0.10 & 4.76 & 8.19 & 2.76 & 1.53 \\
\hline Hole 417D & & & & & & & & & & & \\
\hline $22-1,55$ & $1 \mathrm{~A}$ & 47.7 & 1.72 & 19.1 & 2.48 & 8.34 & 0.08 & 4.61 & 8.77 & 2.70 & 0.90 \\
\hline $22-2,85$ & $1 \mathrm{~A}$ & 48.6 & 1.52 & 16.5 & 6.90 & 5.18 & 0.16 & 6.36 & 10.8 & 2.10 & 0.42 \\
\hline $22-2,85$ & $1 \mathrm{~A}$ & 45.1 & 1.54 & 16.5 & 4.90 & 5.65 & 0.20 & 5.98 & 12.1 & 2.50 & 0.14 \\
\hline $22-6,91$ & $1 \mathrm{~A}$ & 47.7 & 1.39 & 16.5 & 4.36 & 7.13 & 0.14 & 5.56 & 11.7 & 2.41 & 0.50 \\
\hline $26-1,69$ & IA & 44.1 & 1.59 & 16.7 & 5.77 & 5.58 & 0.12 & 6.58 & 10.1 & 2.14 & 0.68 \\
\hline $26-1,69$ & $1 \mathrm{~A}$ & 50.4 & 1.63 & 17.8 & 4.19 & 5.08 & 0.08 & 5.58 & 9.52 & 2.75 & 1.05 \\
\hline $26-6,135$ & $1 \mathrm{~A}$ & 48.3 & 1.36 & 16.8 & 4.22 & 5.46 & 0.14 & 5.87 & 12.1 & 2.44 & 0.78 \\
\hline $27-3,3$ & IB & 46.3 & 1.38 & 16.4 & 7.08 & 2.48 & 0.06 & 5.08 & 5.92 & 2.08 & 1.75 \\
\hline $27-5,74$ & IB & 46.0 & 1.38 & 15.4 & 7.57 & 4.34 & 0.13 & 4.91 & 12.9 & 2.17 & 0.65 \\
\hline $27-5,74$ & & 47.2 & 1.54 & 16.8 & 5.02 & 4.50 & 0.14 & 5.76 & 13.0 & 2.33 & 0.20 \\
\hline $28-1,38$ & $1 \mathrm{~B}$ & 48.4 & 1.49 & 17.2 & 4.57 & 4.58 & 0.14 & 5.56 & 13.0 & 2.47 & 0.06 \\
\hline $28-6,104$ & IB & 48.8 & 1.43 & 16.1 & 2.83 & 7.64 & 0.16 & 7.03 & 11.5 & 2.22 & 0.28 \\
\hline $28-6,104$ & IB & 49.7 & 1.47 & 17.1 & 4.78 & 4.56 & 0.14 & 5.90 & 12.2 & 2.54 & 0.32 \\
\hline $28-6,104$ & & 48.0 & 1.38 & 17.4 & 4.63 & 4.71 & 0.16 & 5.94 & 12.4 & 2.36 & 0.22 \\
\hline $29-2,41$ & $1 \mathrm{C}$ & 63.9 & 0.10 & 5.0 & 8.49 & 1.35 & 0.04 & 10.0 & 1.61 & 0.95 & 1.81 \\
\hline $31-2,93$ & ic & 50.2 & 1.47 & 16.4 & 2.34 & 6.93 & 0.14 & 6.20 & 12.1 & 2.37 & 0.08 \\
\hline $31-2,93$ & & 49.6 & 1.47 & 16.7 & 4.31 & 5.21 & 0.16 & 6.14 & 12.3 & 2.25 & 0.08 \\
\hline $31-4,124$ & 2 & 48.1 & 1.60 & 14.7 & 8.80 & 1.07 & 0.08 & 4.24 & 9.09 & 2.39 & 2.66 \\
\hline $32-2,27$ & 3 & 45.2 & 1.38 & 14.7 & 4.56 & 4.45 & 0.14 & 5.92 & 15.7 & 2.29 & 0.12 \\
\hline $32-2,27$ & & 43.0 & 1.28 & 14.7 & 4.81 & 4.76 & 0.16 & 5.52 & 17.4 & 2.00 & 0.23 \\
\hline $33-2,34$ & 3 & 47.2 & 1.47 & 15.5 & 6.45 & 4.04 & 0.14 & 5.75 & 12.7 & 2.44 & 0.42 \\
\hline $33-4,40$ & 3 & 48.8 & 1.40 & 16.6 & 3.71 & 5.92 & 0.16 & 6.09 & 13.0 & 2.30 & 0.08 \\
\hline $34-2,30$ & 3 & 49.0 & 1.46 & 16.3 & 4.57 & 4.90 & 0.16 & 5.90 & 13.5 & 2.34 & 0.14 \\
\hline $34-5,58$ & 3 & 49.7 & 1.49 & 16.3 & 5.61 & 4.76 & 0.18 & 5.65 & 12,1 & 2.41 & 0.28 \\
\hline $35-4,11$ & 4 & 47.8 & 1.41 & 17.4 & 5.28 & 4.00 & 0.16 & 5.32 & 13.0 & 2.33 & 0.25 \\
\hline $35-4,11$ & & 47.7 & 1.38 & 16.6 & 5.25 & 4.56 & 0.16 & 5.76 & 13.0 & 2.24 & 0.18 \\
\hline $35-4,53$ & 4 & 49.2 & 1.60 & 18.2 & 6.69 & 2.78 & 0.10 & 4.82 & 9.76 & 2.75 & 1.15 \\
\hline $37-6,59$ & 4 & 48.3 & 1.38 & 17.1 & 4.39 & 5.10 & 0.16 & 6.10 & 13.1 & 2.20 & 0.04 \\
\hline $38-2,81$ & 4 & 48.5 & 0.90 & 10.4 & 8.83 & 3.76 & 0.04 & 12.6 & 4.33 & 1.90 & 1.68 \\
\hline $39 \cdot 2,119$ & 4 & 48.7 & 1.78 & 14.6 & 4.94 & 5.39 & 0.16 & 6.14 & 12.8 & 2.46 & 0.12 \\
\hline $39-4,54$ & 4 & 49.7 & 1.34 & 17.3 & 9.10 & 1.26 & 0.04 & 5.69 & 5.83 & 1.87 & 1.46 \\
\hline $39.4,84$ & 4 & 46.6 & 1.39 & 16.6 & 5.91 & 4.29 & 0.15 & 5.76 & 13.8 & 2.28 & 0.15 \\
\hline
\end{tabular}


TABLE 1 - Continued

\begin{tabular}{|c|c|c|c|c|c|c|c|c|c|c|c|c|c|c|c|c|c|}
\hline $\begin{array}{c}\text { Sample } \\
\text { (Interval in } \mathrm{cm} \text { ) }\end{array}$ & $\begin{array}{l}\text { Lithologic } \\
\text { Unit }\end{array}$ & $\mathrm{SiO}_{2}$ & $\mathrm{TiO}_{2}$ & $\mathrm{Al}_{2} \mathrm{O}_{3}$ & $\mathrm{Fe}_{2} \mathrm{O}_{3}$ & $\mathrm{FeO}$ & $\mathrm{MnO}$ & $\mathrm{MgO}$ & $\mathrm{CaO}$ & $\mathrm{Na}_{2} \mathrm{O}$ & $\mathrm{K}_{2} \mathrm{O}$ & $\mathrm{P}_{2} \mathrm{O}_{5}$ & $\mathrm{H}_{2} \mathrm{O}^{+}$ & $\mathrm{CO}_{2}$ & $\mathrm{Cl}$ & Trace & Lithology \\
\hline $39-4,84$ & & 48.3 & 1.38 & 17.5 & 5.32 & 4.67 & 0.16 & 6.01 & 13.8 & 2.25 & 0.12 & 0.12 & 1.1 & 1.6 & & & Second sample \\
\hline $42 \cdot 6,97$ & 5 & 49.3 & 1.56 & 16.1 & 7.17 & 4.37 & 0.14 & 6.33 & 10.3 & 2.35 & 0.67 & 0.14 & 1.90 & 0.4 & & Yes & Basalt (interior) \\
\hline $43-3,36$ & 6 & 48.1 & 1.47 & 16.5 & 6.19 & 4.10 & 0.14 & 6.20 & 12.0 & 2.44 & 0.32 & 0.14 & 0.90 & 1.1 & & Yes & Massive basalt \\
\hline $44-1,60$ & 7 & 48.7 & 1.38 & 14.8 & 7.75 & 4.51 & 0.14 & 6.46 & 10.1 & 2.11 & 0.96 & 0.14 & 1.53 & 0.3 & & No & Basalt (in terior) \\
\hline $44-4,80$ & 7 & 48.3 & 1.57 & 17.3 & 5.70 & 4.22 & 0.14 & 6.76 & 10.8 & 2.55 & 0.12 & 0.16 & 2.46 & 0.6 & & No & Basalt (interior) \\
\hline $50-1,51$ & $8 B$ & 47.7 & 1.37 & 15.0 & 9.50 & 4.21 & 0.14 & 6.52 & 10.0 & 2.07 & 0.95 & 0.16 & 2.22 & 0.5 & & Yes & Basalt \\
\hline $55-5,100$ & $9 \mathrm{~A}$ & 48.4 & 1.58 & 16.0 & 5.76 & 5.66 & 0.20 & 6.37 & 12.6 & 2.16 & 0.22 & 0.14 & 1.07 & 0.5 & & No & Basalt $(6 \mathrm{~cm})$ \\
\hline $64-1,80$ & 9D & 48.6 & 1.35 & 17.1 & 4.54 & 5.77 & 0.18 & 5.73 & 13.2 & 2.07 & 0.04 & 0.10 & 1.5 & 0.0 & & Yes & Basalt (interior) \\
\hline $68-2,67$ & 13 & 50.0 & 1.33 & 16.6 & 4.08 & 4.95 & 0.20 & 6.19 & 13.6 & 2.22 & 0.10 & 0.12 & 0.76 & 1.3 & & No & Basalt (? interior) \\
\hline
\end{tabular}

Note: Data are blank $=$ no value sought. $\mathrm{Cl}$ refers to water-soluble chloride; $\mathrm{Na}_{2} \mathrm{O}$ values corrected for pore water. "Trace" means trace element analysis made. Parenthesis after "basalt" indicates location of sample with respect to pillow margin, where known. In several cases, second samples were taken from the same original 50-g piece of rock and prepared separately; no attempt was made to control the relative location of the two samples.

16) and for the massive, ophitic basalt of Unit 18. Basalt glass measurements from Hole 417D (Sinton and Byerly, this volume) show that $\mathrm{K}_{2} \mathrm{O}$ varies little from a value of about 0.10 weight per cent; even though the original bulk-rock values in Hole $417 \mathrm{~A}$ cannot necessarily be equated to these values, they point to consistently low values for the initial potassium contents. For budgetary calculations, we have assumed an original $\mathrm{K}_{2} \mathrm{O}$ value of 0.11 , based on the 11 "freshest" $417 \mathrm{D}$ basalts that we analyzed. The excess potassium at $417 \mathrm{~A}$ is found to be 690 $\mathrm{g} / \mathrm{cm}^{2}$ for the 200 -meter column drilled.

The relation of potassium with depth for Hole 417A and the top of Hole 417D is shown in Figure 1. The clustering of low values for $417 \mathrm{D}$, with a scattering of higher values, is grossly related to the degree of fracturing and is typical for other drilled sites. Curiously, the relative potassium values for the less-altered Hole 417D are more erratic than for 417A; consequently, the core-by-core estimate of average potassium contents in Hole 417D may not be very meaningful. We find an average composition of about 0.28 per cent with a very high standard deviation for Hole 417D, and estimate the excess potassium to be on the order of $33 \mathrm{~g} / \mathrm{cm}^{2}$ for a 200 -meter column. This value is very likely typical of older "fresh" basalts, but quantitative data to support this speculation are still lacking.

Figure 2 shows the relationship between $\mathrm{K}_{2} \mathrm{O}$ and $\mathrm{H}_{2} \mathrm{O}^{+}$. The samples from Hole 417D show the typical, somewhat erratic rise of $\mathrm{K}_{2} \mathrm{O}$ with absorbed water seen at most oceanic basalt sites. The Hole 417A samples, however, show a tendency toward much higher values of $\mathrm{K}_{2} \mathrm{O}$ at given water values, especially in the brecciated basalts and "red-brown"' basalt margins. This figure suggests that these rocks have been exposed to amounts of water far in excess of most oceanic basalts, and that the absorption of potassium may continue long after the rock has absorbed all of the water that it can.

\section{Calcium}

As Figure 3 shows, calcium is depleted as strikingly as potassium is enriched, with an inverse relation between these elements. The most potassium-enriched rocks are also the most depleted in calcium. The hyaloclastite is fairly uniform and low in calcium. The shallower basalts which are "fresh" in appearance have lost approximately twothirds of their original calcium, and the most severely altered rocks have lost about nine-tenths.

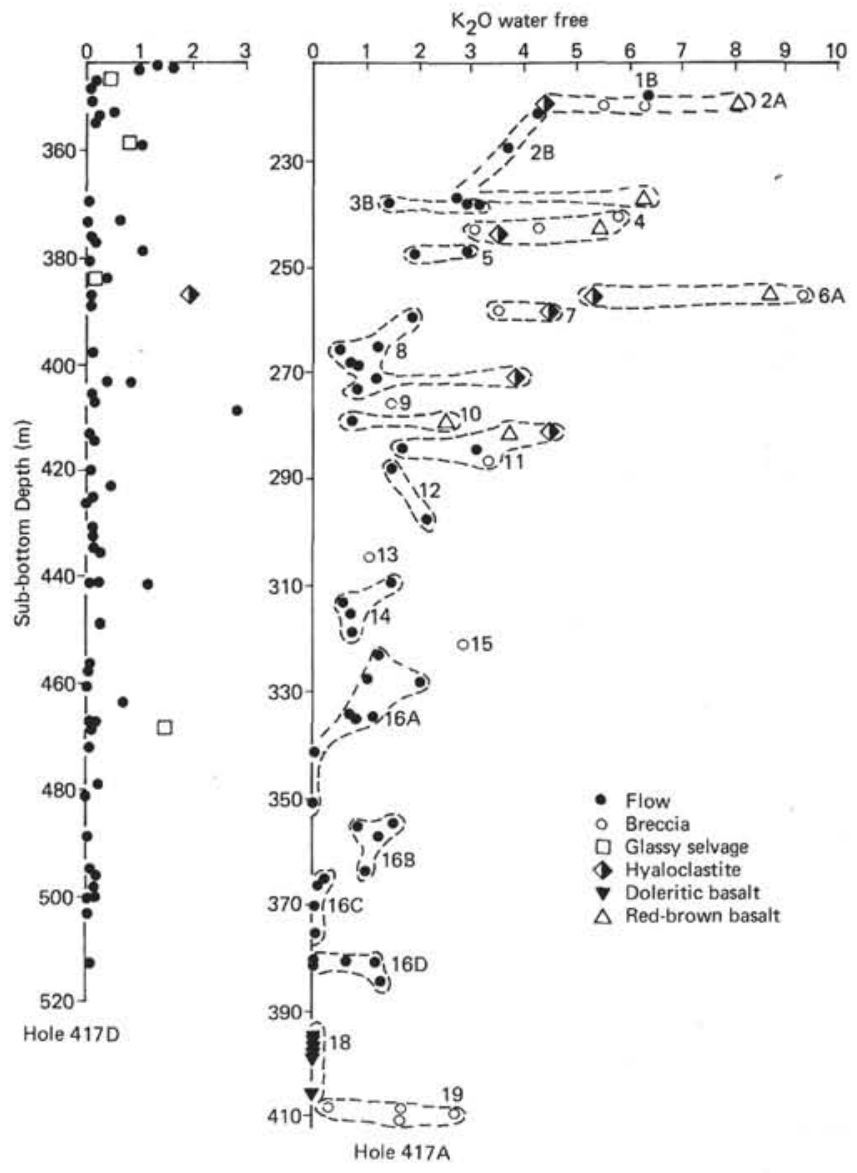

Figure 1. Weight per cent $\mathrm{K}_{2} \mathrm{O}$, calculated on a water-free basis, versus depth in Holes $417 \mathrm{~A}$ and $417 \mathrm{D}$. The tops of the basalt have been matched in position. Lithologic units, as defined in the Site 417 Report (this volume), are circles where more than one sample is given, and identified by italicized number. "Doleritic basalt" refers to massive basalt of Unit 18.

Plagioclase feldspar is commonly replaced by K-feldspar, or by largely unidentified zeolites. Two calcium zeolite species (chabazite and ?species) have been identified; their significance is not understood. The release of calcium raises the amount of this ion in the water, and abundant calcite occurs in veins and cavities. Aragonite is uncommon but 

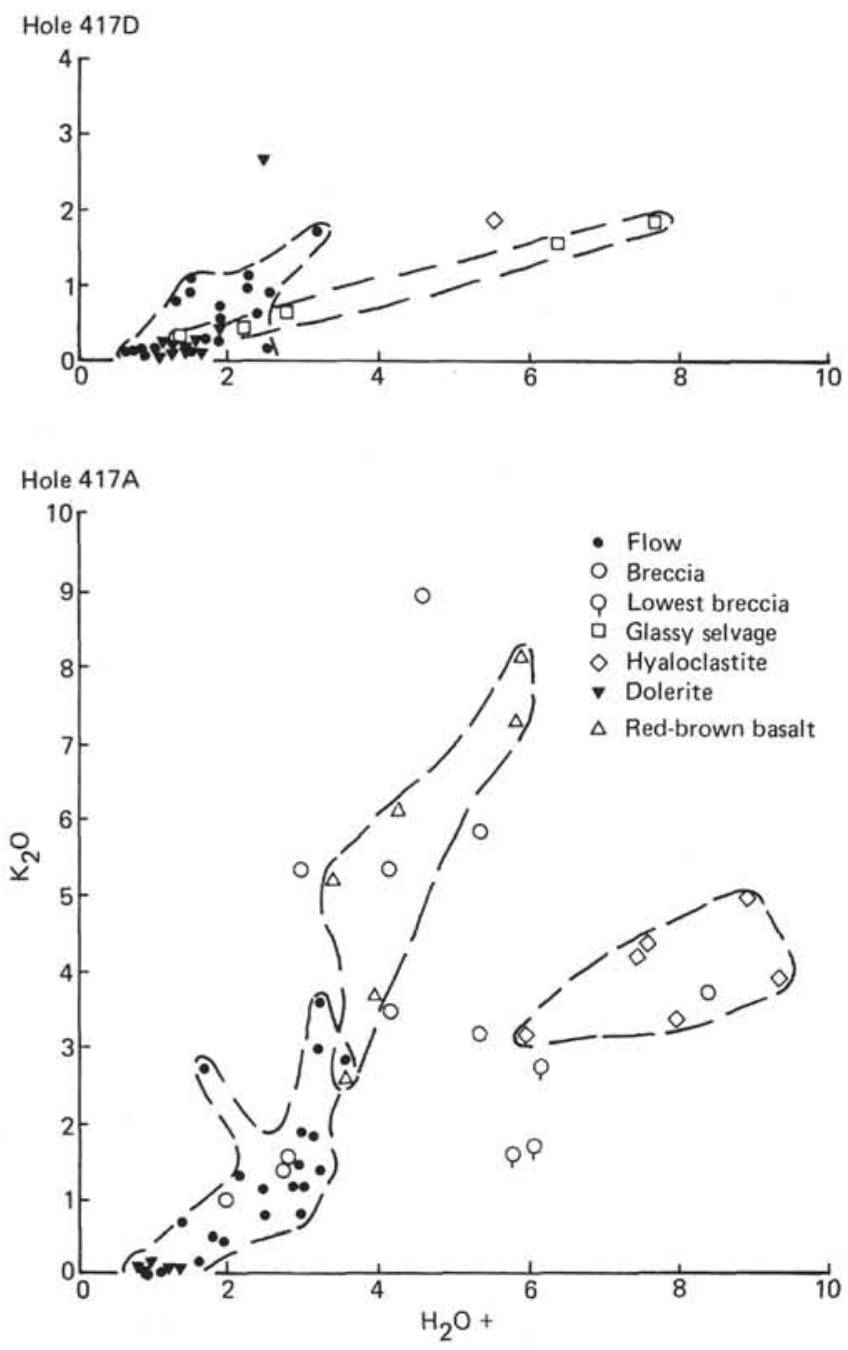

Figure 2. Weight per cent $\mathrm{K}_{2} \mathrm{O}$ versus weight per cent $\mathrm{H}_{2} \mathrm{O}^{+}$ in Holes $417 A$ and $417 D$. Some lithologic groups are circled. "Lowest breccia" refers to Unit 19, Hole 417A. "Dolerite" refers to Unit 18, Hole $417 \mathrm{~A}$.

has been found in both holes. Thus, the alteration process which removes calcium from the rock does not release all of this element into the sea.

\section{Magnesium}

The removal of magnesium parallels that of calcium (Figure 4), but the amounts removed are far less. Hyaloclastites are less magnesium depleted than the altered basalts, but in no case are they magnesium enriched. In other environments considered to represent higher temperature alteration, magnesium is enriched rather than depleted (Humphris and Thompson, 1978), suggesting that the flux of this element depends critically on the conditions of the alteration process (Thompson and Humphris, 1977). In the present case, however, there is little doubt that depletion is the general rule.

\section{Sodium}

Although fewer analyses of sodium were available for this study, this element appears to be slightly depleted
(Figure 5). Fresher samples have abundant plagioclase, but more altered rocks have $\mathrm{K}$-feldspar and zeolites replacing the plagioclase.

\section{Boron}

This element (Table 2) is clearly enriched in the altered samples with the greatest enrichments found in the hyaloclastites. The overall uptake of boron cannot be calculated on the basis of these data, but a comparison of potassium/ boron ratios (about 470 in the breccias and altered basalts, 410 in the "fresher"' basalts, and 310 in the hyaloclastites, with values closer to 100 in the fresher basalts of $417 \mathrm{D}$, and a ratio of 87 in sea water) show that potassium is more efficiently scavenged from sea water than is boron.

\section{Lithium}

This element is enriched, with the relatively smectite-rich hyaloclastites showing the highest values. There is, however, no convincing coherence between $\mathrm{K}$ and $\mathrm{Li}$. The sea water $\mathrm{K} / \mathrm{Li}$ ratio is about 2290 , and that of the $417 \mathrm{D}$ samples analyzed is about 500 . The brecciated basalts of $417 \mathrm{~A}$ have a ratio of 1200 , the hyaloclastites have 600 , and the "fresher"' flows have 800 . Because the values show considerable scatter, we cannot say whether or not lithium is removed more or less efficiently from sea water than is potassium.

\section{Barium}

The barium balance cannot be calculated. Flows and brecciated basalts from 417A are enriched in barium parallel to the enrichment in potassium; 417D samples have a $\mathrm{K} / \mathrm{Ba}$ ratio of 680 , the $417 \mathrm{~A}$ flows have 600 , and the breccias have 400 , all with high scatter. The hyaloclastites, however, have so little barium that the $\mathrm{K} / \mathrm{Ba}$ ratio cannot be determined. The sea water $\mathrm{K} / \mathrm{Ba}$ ratio is about 20,000 , and if barium could be shown to be taken into the altered basalts more efficiently than potassium, it would be the critical, or limiting, element for chemical exchange. The source for barium need not be the sea water; a small amount of trapped calcareous sediment (such as is found within the 417D basalts) could supply more than enough barium.

\section{Nickel}

This element is variably distributed in both holes and shows no coherence with $\mathrm{Mg}$, even in the freshest samples. The altered rocks in Hole 417A have comparable levels of nickel to those in $417 \mathrm{D}$, but the smectite-rich hyaloclastites have somewhat higher values. An overall enrichment or depletion cannot be demonstrated.

\section{Chromium}

Chromium is very slightly enriched in all 417A samples compared to those from $417 \mathrm{D}$, using titanium as a normalizing element. The source of the excess chromium is not known, but sea water is possible.

\section{Copper}

This element is slightly depleted in the altered basalt and enriched in the hyaloclastites. Two samples collected from Core 417A-24, where native copper was identified, have 


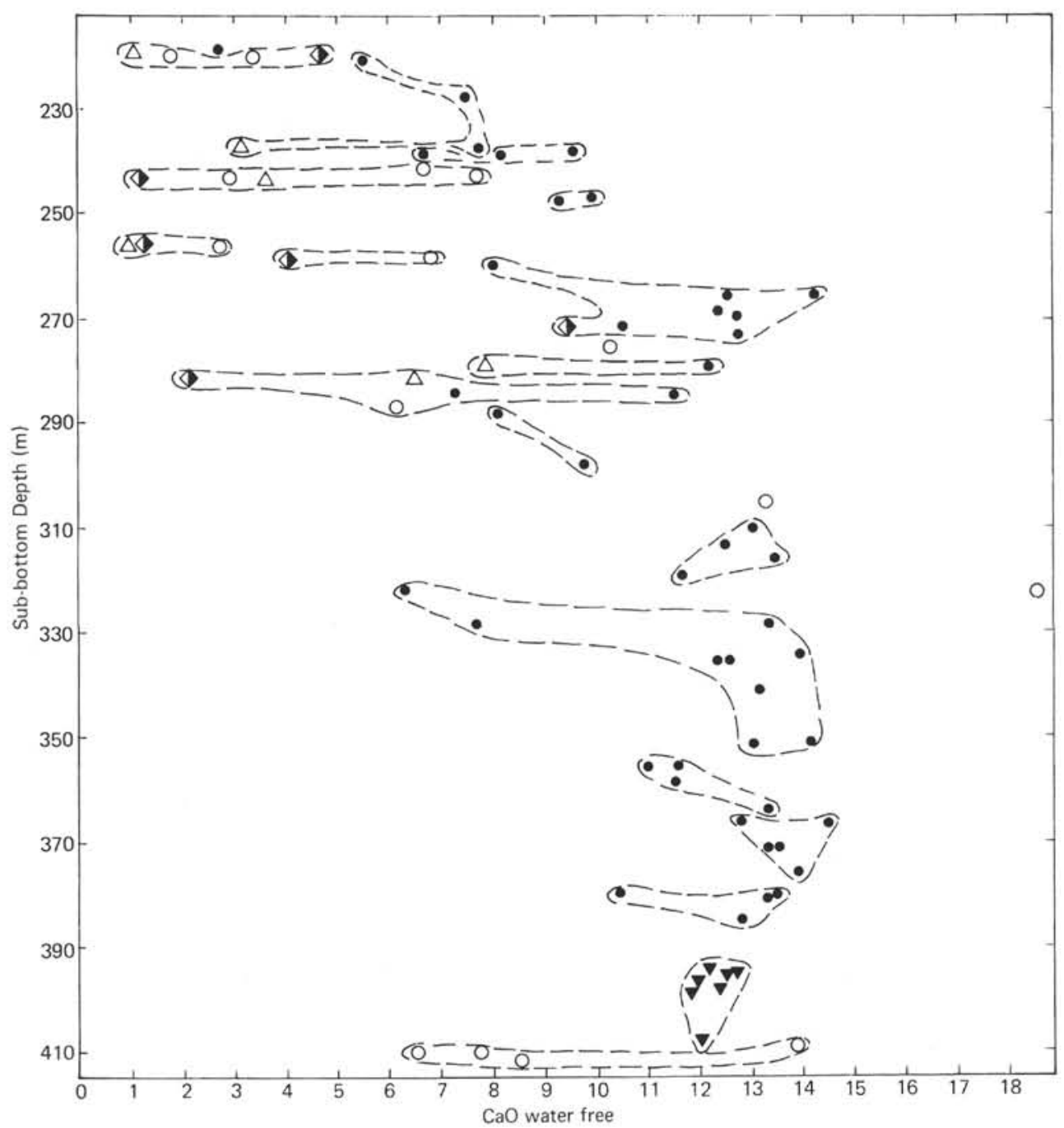

Figure 3. Weight per cent $\mathrm{CaO}$, calculated on a water-free basis, versus depth in Hole 417A. Symbols as in Figure 1.

slightly low values of copper, showing that the occurrence of this mineral is not tied to the introduction of copper from external sources. Instead, the reduction of copper to the native form is probably related to the oxidation of iron.

\section{Vanadium}

Normalized to titanium, this element is relatively invariable in all of the altered basalt samples, but is slightly depleted in the hyaloclastites. The stability of iron-titanium oxides (in spite of their oxidation) suggests that much of the vanadium can reside in these minerals.

\section{Yttrium}

Our data show that yttrium is changed only in the hyaloclastites, from which it has been removed to a remarkable extent. Because the rare earth elements are relatively stable in the altered basalts, the persistence of yttrium in these altered rocks is not surprising. Unfortunately, no rare earth data are available from the hyaloclastites.

\section{Strontium}

Contrary to the conclusions of other investigators, these samples show no strontium enrichment. The hyaloclastites, in fact, are mildly depleted.

\section{Zirconium}

Like titanium, this element is nearly constant in all of the rock types. Not surprisingly, the $\mathrm{Ti} / \mathrm{Zr}$ ratio is the most nearly constant of the elemental ratios in all samples, fresh and altered. There is a slight enrichment of $\mathrm{Ti}, \mathrm{Zr}$, and $\mathrm{Fe}$ in the very highly altered ("red-brown") basalts and a concomitant decrease in the adjacent hyaloclastites, which probably reflects a loss of other elements from the basalt. The lower contents of $\mathrm{Ti}, \mathrm{Zr}, \mathrm{Fe}$, and $\mathrm{Y}$ (as well as several other elements) in the hyaloclastites is not easily explained; dilution will not suffice, and we conclude that several normally stable elements are slightly and coherently depleted in this rock type. An originally lower value is not easily accepted; the hyaloclastites were probably higher in glass and lower in phenocrysts than the basalts, and most of 


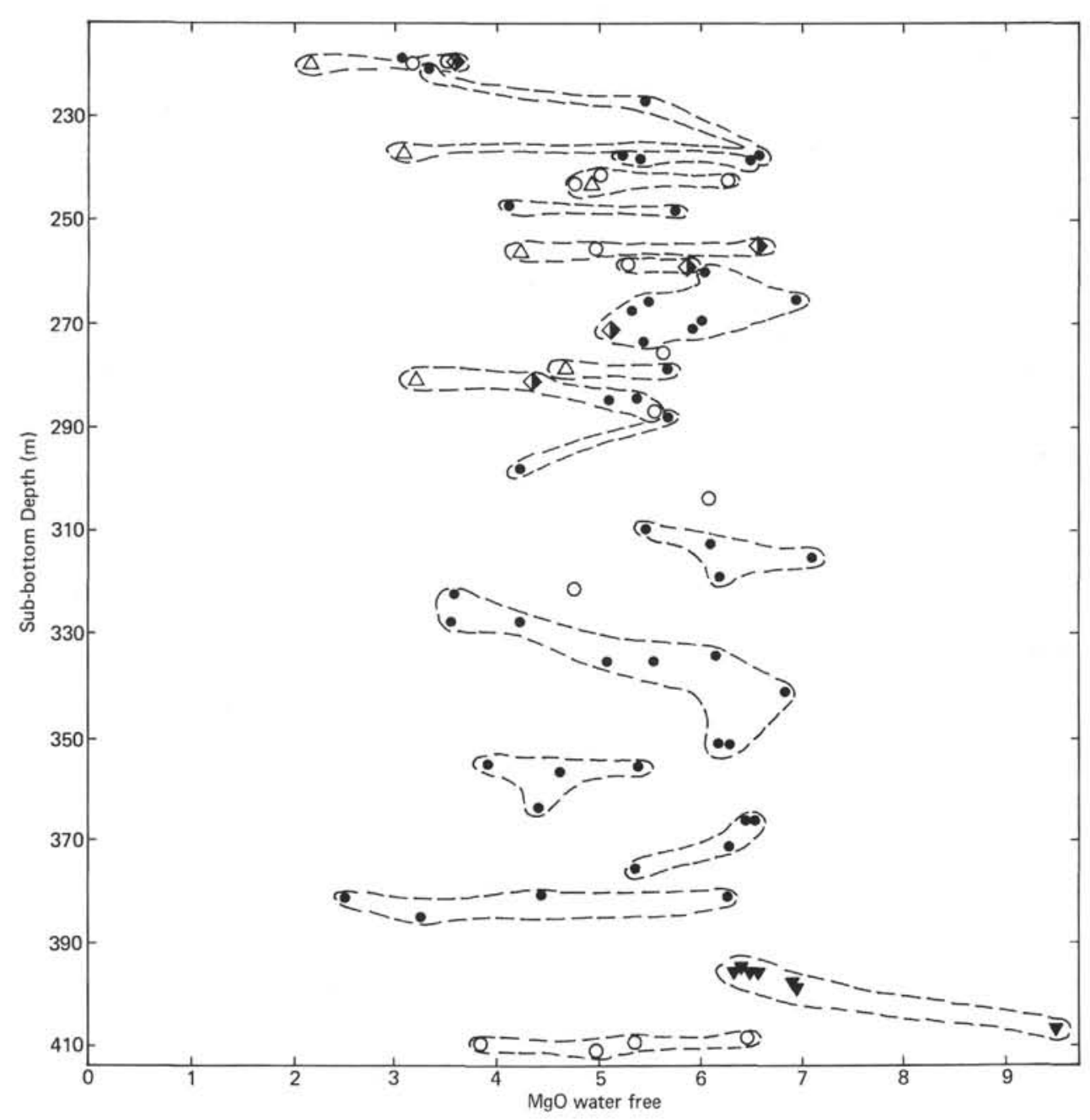

Figure 4. Weight per cent $\mathrm{MgO}$, calculated on a water-free basis, versus depth in Hole 417A. Symbols as in Figure 1.

these elements are relatively depleted in the plagioclase phenocrysts.

\section{Oxidation of the Iron}

As shown in Figure 6, the relative values of ferric to ferrous iron are related to water content in the two sites, as is the general case for oceanic basalts. One notable exception was found: the K-enriched breccia of Unit 19, the deepest unit in Hole 417A, has the lowest ferric/ferrous ratio for either hole, including the "fresh" basalts at both sites. There is no immediate explanation for this reduction of the iron, but the bottom waters were known to be periodically reduced during the black claystone episode of the Middle Cretaceous. There are several difficulties in invoking the influence of high reduced bottom waters, not the least of which is that Unit 19 of Hole 417A occurs 100 meters lower than the reduced black clays of Hole 417D.

A comparison of the ferric and ferrous values of both the altered and "fresh" basalts in Holes 417A and 417D with the putatively fresh, younger basalts at Site 332 (Robinson et al., 1977), shows that all of the Site 417 basalts are more oxidized than the younger samples of Site 332. Many of the basalts with relatively high values of ferric iron (including the very low-potassium massive basalts of Unit 18 , Hole $417 \mathrm{~A}$ ) have a very fresh mineralogy, as shown by the presence of olivine with only slight marginal alteration. It is tempting to speculate that iron oxidation is a process which never really ceases, as long as some cracks allow the circulation of small amounts of oxygenated water through the rock.

\section{Iron, Titanium, Aluminum, and Silicon}

These elements are unchanged in the alteration process. The variability of these elements in the original rock is probably low, except that these plagioclase-phyric rocks undoubtedly have values of aluminum more scattered than the other elements. An inspection of the data shows that there is no gain or loss of $\mathrm{Fe}$ or $\mathrm{Si}$ relative to $\mathrm{Ti}$ or $\mathrm{Al}$ as a function of $\mathrm{K}$ uptake. However, the fresh basalts of Hole 417D appear to have a slightly higher $\mathrm{Al}$ content than the mean of the $417 \mathrm{~A}$ basalts. A small difference in plagioclase content could account for this difference; otherwise, a less probable coherent change of $\mathrm{Fe}, \mathrm{Ti}$, and $\mathrm{Si}$ with respect to $\mathrm{Al}$ would be required and the change would have to affect rocks of all degrees of alteration approximately equally in Hole 417A. 


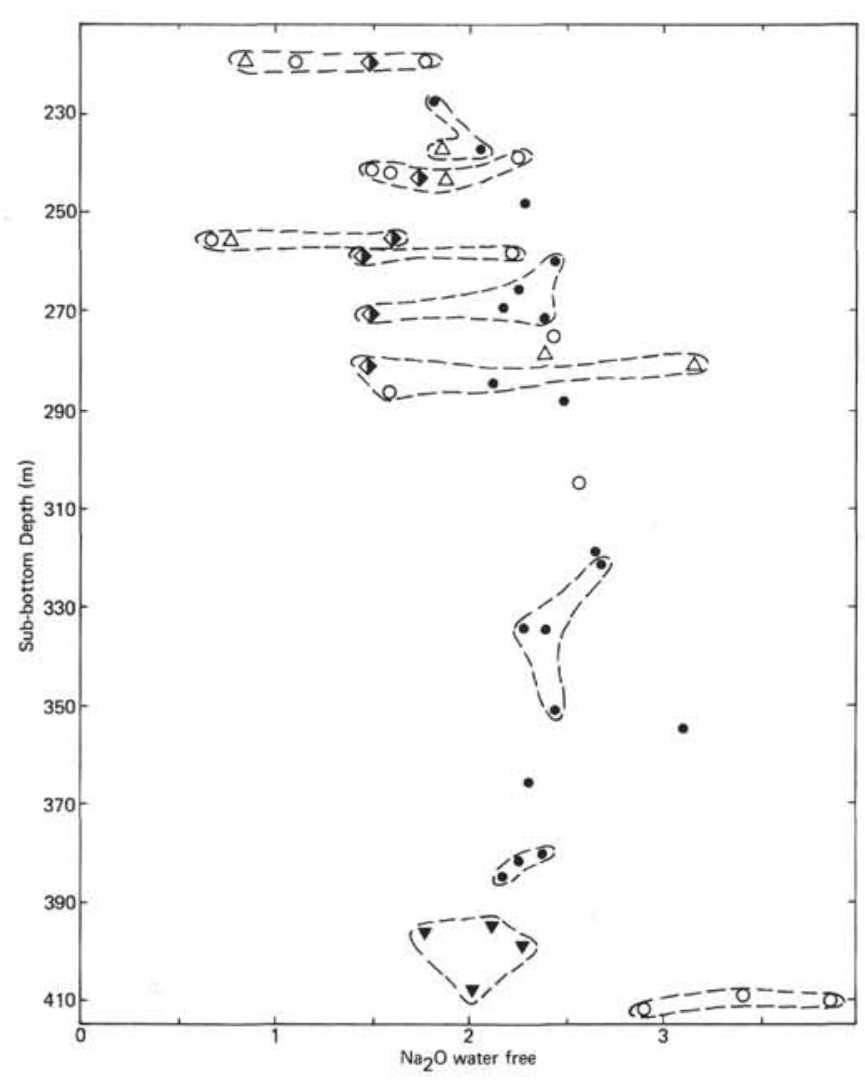

Figure 5. Weight per cent $\mathrm{Na}_{2} \mathrm{O}$, calculated on a water-free basis, versus depth in Hole 417 A. Symbols as in Figure 1.

\section{BUDGET OF ALTERATION}

The relatively high recovery of rock in Hole $417 \mathrm{~A}$ permits an estimate to be made (Table $3 \mathrm{~A}$ ) of the total flux of major elements for the 200-meter column of rock drilled. The calculation was made by averaging the composition of the basalt for each core, and calculating the weight of each oxide in each core using measured rock densities. Hyaloclastite was found (six samples) to have a consistent chemical composition throughout and an average dry-bulk density of $1.5 \mathrm{~g} / \mathrm{cm}^{3}$. The fraction of basalt and hyaloclastite was measured from photographs, and unrecovered intervals were assigned the values of adjacent recovered intervals. The composition of the presumed original fresh basalt was determined by averaging the freshest samples from Hole 417D. Thus, for purposes of calculation, the minor alteration and potassium uptake in Hole 417D is minimized. The original density and porosity of the basalts in Hole 417A is not known, but can be estimated if we assume that some chemical element has been unchanged during alteration, and we know the weight percentage of this element in Hole 417D. As Table 3A shows, if we assume a constancy of aluminum, then the basalt in Hole 417A must have had a porosity of 6 per cent (assuming no open fractures), if the rock density was originally $2.9 \mathrm{~g} / \mathrm{cm}^{3}$. There is some reason to believe that aluminum might not be the best normalizing element; the abundance of phyric plagioclase casts some suspicion on the constancy of this element, and the amount of $\mathrm{Al}$ relative to $\mathrm{Ti}, \mathrm{Fe}$, and $\mathrm{Si}$ is slightly higher in Hole 417D, even though the latter three elements are fairly constant with respect to each other. A second calculation, assuming that titanium (instead of aluminum) is constant, gives an original porosity of 13 per cent, which seems to be more in accord with measured and inferred values for shallow portions of the crust (see Site 417 Report, this volume).

A further problem in calculating the chemical exchange is that the oxidation state of the original iron is not known. Calculations have been made using differing values of original ferric iron, and their effect on the total chemical change is fairly minor.

As Figure 7 shows, the loss of calcium, magnesium, and sodium is not balanced by the gain of potassium. The only ion available to maintain electrostatic constancy is hydrogen, which we assume must come from the breakdown of bicarbonate ion, producing hydrogen ion for alteration and creating carbonate ion in the water. The balance of chemical species gained and lost under differing assumptions is shown in Table $3 \mathrm{~A}$. We are assuming that the relative gains and losses of total iron, silicon, aluminum, and titanium are sufficiently small that they are not included in the balance. Potassium is the principal metallic ion gained from sea water, but hydrogen is the apparent major absorbed species. Calcium is the principal effluent metallic ion, and carbonate is the principal ionic species. There is a slight uptake of phosphorus and a loss of manganese shown by these equations, but neither element changes very much.

The alteration process takes up potassium, phosphorus, and bicarbonate, and releases calcium, manganese, sodium, carbonate, and oxygen (probably as water). The minor phosphorus could be obtained from small amounts of trapped calcareous ooze, as well as sea water, but the very large amounts of potassium ultimately must come from sea water.

The hydrogen ion taken up during alteration combines with oxygen released to form water, as shown in Table 3B. The oxygen consumed during oxidation of the iron must come from dissolved oxygen in sea water. If we assume that the oxygen content of the sea water is about $4 \mathrm{ml} / \mathrm{l}$, then the molecular ratio $\mathrm{K}^{+} / \mathrm{O}_{2}$ is about 56 , and (as Table $3 \mathrm{~B}$ shows) oxygen might be a limiting species, requiring on the order of 20 times as much water for alteration as does potassium. Bicarbonate poses a parallel problem; it is normally present in about one-fifth the molecular abundance of potassium in sea water, and it might require a similarly large amount of water to accomplish the alteration. However, in the case of oxygen, we know neither the oxygen content of the water, nor (more importantly) that the oxidation was completed during the process of chemical exchange. In fact, the higher contents of ferric iron in the otherwise fresh (low K) Units 16 and 18 of Hole 417A and in all of Hole 417D, especially when compared to the younger basalts of Holes $332 \mathrm{~A}$ and 332B (Robinson et al., 1977), suggest that oxidation may continue long after other types of alteration have been completed. In the case of bicarbonate, we do not know the $\mathrm{HCO}_{3}-$ content of the altering water; if it passed initially downward through sediment before entering the basalt, it might have acquired considerable initial alkalinity. Thus, in assuming that potassium is the limiting species, we are proposing a highly conservative limiting case. Doubtless, 
TABLE 2

Minor Element Chemical Composition of Samples From Holes 417A and 417D

\begin{tabular}{|c|c|c|c|c|c|c|c|c|c|c|c|c|}
\hline \multirow{2}{*}{$\begin{array}{c}\text { Sample } \\
\text { (Interval in } \mathrm{cm})\end{array}$} & \multicolumn{12}{|c|}{$\mathrm{ppm}$} \\
\hline & B & $\mathrm{Li}$ & $\mathrm{Ni}$ & Co & $\mathrm{Cr}$ & $\mathrm{Cu}$ & $\mathrm{V}$ & $\mathrm{Y}$ & $\mathrm{Zr}$ & $\mathrm{Sr}$ & $\mathrm{Ba}$ & Lithology \\
\hline \multicolumn{13}{|l|}{ Hole 417A } \\
\hline $24-2,4$ & 130 & 52 & 90 & 48 & 430 & 71 & 290 & 74 & 145 & 105 & 175 & Breccia \\
\hline $24-2,58$ & 110 & 39 & 66 & 32 & 520 & 39 & 440 & 63 & 170 & 110 & 165 & Red-brown basalt \\
\hline $25-1,57$ & 41 & 49 & 71 & 45 & 410 & 39 & 350 & 60 & 130 & 170 & 445 & Basalt \\
\hline $26-1,31$ & 64 & 32 & 55 & 22 & 460 & 66 & 390 & 64 & 160 & 200 & 315 & Red-brown basalt \\
\hline $26-1,39$ & 59 & 27 & 77 & 32 & 295 & 83 & 285 & 59 & 120 & 120 & 120 & Basalt $(6 \mathrm{~cm})$ \\
\hline $26-3,86$ & 68 & 39 & 60 & 21 & 415 & 105 & 305 & 80 & 145 & 160 & 115 & Breccia \\
\hline $26-5,72$ & 110 & 49 & 82 & 51 & 160 & 91 & 250 & $<5$ & 57 & 43 & $<5$ & Hyaloclastite \\
\hline $26-5,72$ & 90 & 30 & 69 & 27 & 515 & 185 & 415 & 46 & 165 & 155 & $<5$ & Red-brown basalt \\
\hline $27-2,15$ & 78 & 21 & 68 & 42 & 315 & 125 & 345 & 47 & 120 & 130 & 9 & Basalt \\
\hline $28-1,36$ & 86 & 25 & 66 & 20 & 680 & 115 & 630 & 86 & 190 & 160 & 83 & Red-brown basalt \\
\hline $28-1,36$ & 51 & 28 & 62 & 26 & 540 & 140 & 335 & 51 & 145 & 200 & 76 & Breccia \\
\hline $28-1,36$ & 100 & 56 & 80 & 44 & 255 & 70 & 125 & $<5$ & 55 & 70 & 12 & Hyaloclastite \\
\hline $28-2,131$ & 61 & 34 & 63 & 27 & 370 & 190 & 260 & 56 & 115 & 190 & 73 & Breccia \\
\hline $28-2,131$ & 120 & 55 & 79 & 28 & 245 & 70 & 105 & $<5$ & 80 & 68 & 10 & Hyaloclastite \\
\hline $29-3,132$ & 36 & 15 & 41 & 30 & 260 & 68 & 315 & 37 & 100 & 115 & $<5$ & Basalt $(15 \mathrm{~cm})$ \\
\hline $30-3,106$ & 54 & 19 & 36 & 29 & 445 & 200 & 375 & 45 & 135 & 205 & 54 & Red-brown basalt \\
\hline $30-5,24$ & 59 & 19 & 39 & 23 & 540 & 125 & 455 & 53 & 160 & 185 & 45 & Red-brown basalt \\
\hline $30-5,24$ & 125 & 79 & 71 & 31 & 470 & 97 & 155 & $<5$ & 105 & 105 & 10 & Hyaloclastite \\
\hline $36-2,95$ & 23 & 20 & 50 & 52 & 255 & 84 & 290 & 36 & 91 & 105 & $<5$ & Basalt (interior) \\
\hline $38-3,70$ & 4 & 7 & 120 & 52 & 345 & 105 & 315 & 39 & 110 & 77 & $<5$ & Basalt $(25 \mathrm{~cm})$ \\
\hline $38-6,76$ & 44 & 29 & 44 & 30 & 360 & 41 & 310 & 56 & 105 & 130 & 80 & Basalt (edge) \\
\hline $40-2,130$ & 8 & 10 & 112 & 63 & 285 & 100 & 295 & 37 & 105 & 95 & $<5$ & Basalt (interior) \\
\hline $42-1,110$ & 43 & 12 & 78 & 26 & 365 & 64 & 305 & 43 & 120 & 105 & 41 & Basalt (edge) \\
\hline $42-4,118$ & 56 & 11 & 71 & 33 & 350 & 43 & 325 & 53 & 110 & 115 & 17 & Basalt (edge) \\
\hline $43-5,8$ & 8 & 6 & 67 & 60 & 255 & 94 & 315 & 39 & 98 & 100 & $<5$ & Massive basalt \\
\hline $44-4,5$ & 3 & 7 & 64 & 38 & 370 & 80 & 390 & 46 & 110 & 125 & $<5$ & Massive basalt \\
\hline $46-2,44$ & 76 & 22 & 48 & 27 & 435 & 25 & 390 & 53 & 115 & 415 & 59 & Breccia \\
\hline $46-3,17$ & 46 & 20 & 100 & 27 & 365 & 65 & 315 & 65 & 120 & 360 & 23 & Breccia \\
\hline \multicolumn{13}{|l|}{ Hole 417D } \\
\hline $22-1,55$ & 29 & 13 & 110 & 59 & 520 & 115 & 415 & 42 & 125 & 125 & 7 & Basalt \\
\hline $22-2,85$ & 14 & 10 & 110 & 60 & 230 & 100 & 335 & 44 & 115 & 110 & $<5$ & Basalt $(2 \mathrm{~cm})$ \\
\hline $22-2,85$ & 22 & 15 & 68 & 54 & 260 & 130 & 330 & 40 & 105 & 105 & 7 & Glassy selvage \\
\hline $26-1,69$ & 25 & 17 & 64 & 45 & 260 & 140. & 325 & 42 & 110 & 110 & 7 & Glassy selvage \\
\hline $26-6,135$ & 18 & 7 & 87 & 53 & 265 & 94 & 380 & 47 & 115 & 155 & $<5$ & Basalt $(2 \mathrm{~cm})$ \\
\hline $27-5,74$ & 6 & 14 & 145 & 65 & 285 & 90 & 410 & 51 & 120 & 155 & $<5$ & Basalt $(>6 \mathrm{~cm})$ \\
\hline $28-6,104$ & 11 & 7 & 92 & 48 & 270 & 86 & 345 & 44 & 110 & 145 & $<5$ & Basalt (2 cm) \\
\hline $31-2,93$ & 4 & 9 & 86 & 45 & 285 & 94 & 360 & 44 & 110 & 145 & $<5$ & Basalt (interior) \\
\hline $31-4,124$ & 19 & 56 & 99 & 48 & 305 & 46 & 400 & 41 & 130 & 140 & 50 & Basalt (interior) \\
\hline $32-2,27$ & 15 & 7 & 105 & 48 & 250 & 96 & 320 & 45 & 110 & 160 & $<5$ & Massive basalt \\
\hline $35-4,11$ & 9 & 7 & 125 & 50 & 285 & 90 & 340 & 46 & 110 & 145 & $<5$ & Basalt $(8 \mathrm{~cm})$ \\
\hline $39-4,54$ & 70 & 31 & 61 & 23 & 280 & 105 & 240 & 20 & 85 & 75 & 23 & Glassy selvage \\
\hline $39-4,84$ & 6 & 7 & 93 & 43 & 275 & 87 & 340 & 43 & 105 & 115 & $<5$ & Basalt $(6 \mathrm{~cm})$ \\
\hline $42-6,97$ & 39 & 7 & 59 & 35 & 260 & 100 & 345 & 44 & 115 & 105 & $<5$ & Basalt (interior) \\
\hline $43-3,36$ & 16 & 8 & 97 & 54 & 300 & 67 & 385 & 45 & 115 & 145 & $<5$ & Massive basalt \\
\hline $50-1,51$ & 38 & 9 & 42 & 25 & 190 & 75 & 290 & 38 & 98 & 86 & $<5$ & Basalt \\
\hline $64-1,80$ & 11 & 9 & 88 & 46 & 230 & 88 & 335 & 40 & 100 & 130 & $<5$ & Basalt (interior) \\
\hline
\end{tabular}

Note: Lithology designations are the same as in Table 1.

far more water moved through the system than these estimates suggest.

For the two cases (titanium constant or aluminum constant), we calculate slightly different volumes of the amount of sea water required to alter the basalt, assuming that the limiting element (potassium) is completely removed. Because the two cases lead to different original porosities, we find two quite different values for the ratio between the volume of water required and the volume of voids, i.e., number of times the water in the voids must be replaced. In the aluminum-constant case, we find an original porosity of 6 per cent, a required volume of $1.76 \mathrm{~m}^{3} / \mathrm{cm}^{2}$, column 200 meters long, and 1570 replacement cycles. For constant titanium, these figures are 13 per cent, $1.66 \mathrm{~m}^{3}$, and 642 cycles.

The discharge of calcium and carbonate ion seriously supersaturates the water in calcium carbonate. The total excess corresponds to an accumulation of about 24 meters of $\mathrm{CaCO}_{3}$ in the constant-aluminum case, and 20 meters in the constant-titanium case per 200 meters of basalt. Much of this excess calcite is now seen as the ubiquitous void and fracture fillings, but much is probably discharged into sea water. Sea water is generally close to saturation at the depths of most mid-ocean ridges; the effect of discharge of $\mathrm{Ca}$ and $\mathrm{CO}_{3}$ ions into sea water might be to supersaturate it, or raise it to the saturation level if it were slightly under- 


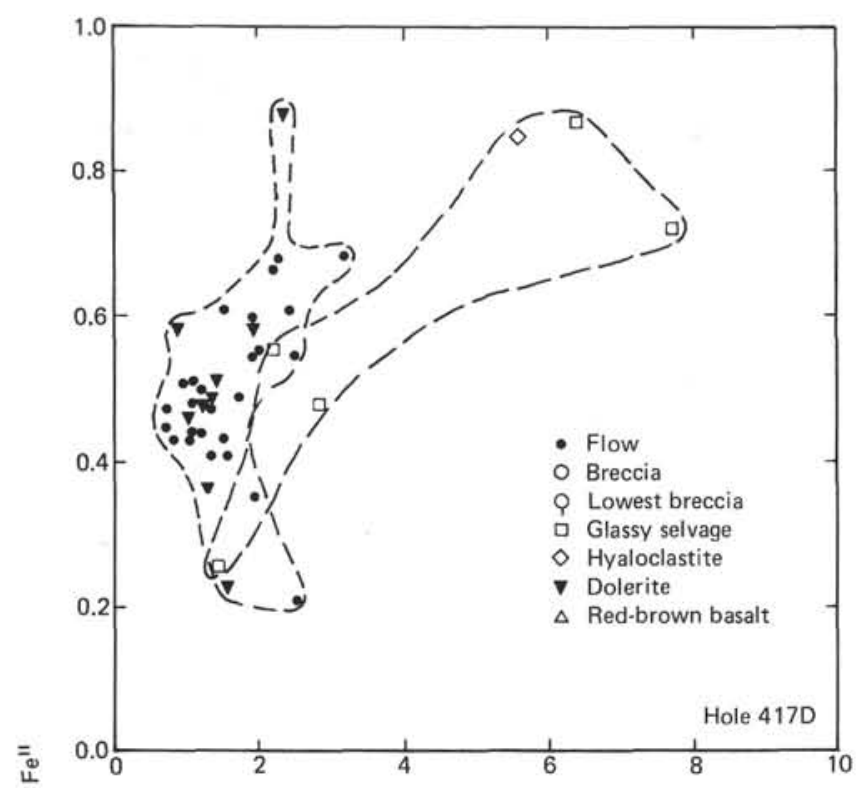

carbonate) or dissolved oxygen is limiting, or if removal of the limiting species is less than complete, the number of void fillings increases correspondingly. Therefore, we have calculated the "easiest" case. We do not believe that simple diffusion of water, or undriven penetration into open fractures, will enable enough water to be available, especially at 200 meters beneath the surface. We also note that oxygen isotopic measurements (Muehlenbachs, this volume) consistently point to a slightly warm temperature, relative to sea water. Therefore, we propose that the alteration process is caused by a slow convection of water through the cooling oceanic crust. The consistently higher temperatures here record upward-moving water, which passed downward into the crust over an unknown lateral extent. The isotopic studies of the alteration at Site 417A (Muehlenbachs, this volume) suggest normal sea water as the alteration fluid; we have assumed likewise. However, we recognize that if sea water penetrated to significant depths and was heated to temperatures of $200^{\circ}$ to $400^{\circ} \mathrm{C}$, then reaction with basaltic rocks would result in sea water solutions depleted in sulfate and magnesium and enriched in potassium and hydrogen ion (Bischoff and Dickson, 1975; Humphris and Thompson, 1978; Mottl, 1976, in press). That the basalts of Hole $417 \mathrm{~A}$ reacted with the cooled upwelling solutions from a deeper hydrothermal system is a possibility. However, the weight of evidence (particularly the isotopic data) favors the hypothesis that the alteration occurred with sea water of normal or close to normal composition.

The convective process consists of long-duration cells, the effluent positions of which might be determined by topographic singularities. Thus, a topographic high, which remains sediment free and exposes its fractured rock directly to sea water, might become the preferred site for effluence. The ratio of the broad area of minor downward penetration of water, compared to the area of local effluence of warmed water with its alteration products, is not known. Sites such as Hole 417A appear to be scarce in the experience of deep-sea drilling, but this scarcity could be due to a site-selection bias toward sediment ponds when seeking young crust (to allow spudding-in), and toward buried ponds when seeking old crust (to acquire the oldest sediments). If, on the other hand, the permeability of sediment-covered basalt in topographic depressions is markedly lower than that of sediment-free, topographically high basalt, then the ratio of areas corresponding to the two phenomena might be quite high.

The heat necessary to drive the convective water can be

saturated. A common observation, exemplified clearly at Hole 417D, is that the basal meter or so of sediment has nearly perfect preservation of the calcareous fossils and is overlain immediately by sediment with no preserved carbonate. We speculate that the interval of preservation corresponds to an important discharge of the products of alteration, even though the vent from which the effluents issue may be several hundred meters away. Thus, a deeper "pseudo-lysocline" may often accompany alteration of ridge basalts.

The entire process of alteration requires a mechanism for driving the large amounts of water required. Our estimates assume that potassium is the limiting species, and require that it be removed completely. If hydrogen ion (bicalculated by assuming a temperature rise of $30^{\circ} \mathrm{C}$ (corresponding to oxygen isotopic measurements). The heat for the case of constant aluminum and constant titanium is nearly the same, because the volumes of water moved are nearly the same. They correspond to about $2.34 \times 10^{7}$ calories for a $1 \mathrm{~cm}^{2}$ column 200 meters long. The original heat in an equivalent column of basalt, assuming $100 \mathrm{cal} / \mathrm{g}$ for latent heat of cooling and $0.3 \mathrm{cal} / \mathrm{g}^{\circ} \mathrm{C}$ for specific heat of cooling could not in itself supply more than half the necessary heat. We could heat no more than $0.8 \mathrm{~m}^{3}$ of water with this basalt, but we need to cycle through at least 1.7 to $1.8 \mathrm{~m}^{3}$. Thus, the heat necessary must come in part from depths greater than the observed alteration, i.e., the cooling crust in general. 
TABLE 3A

Budgetary Calculations for Alteration in Hole 417A

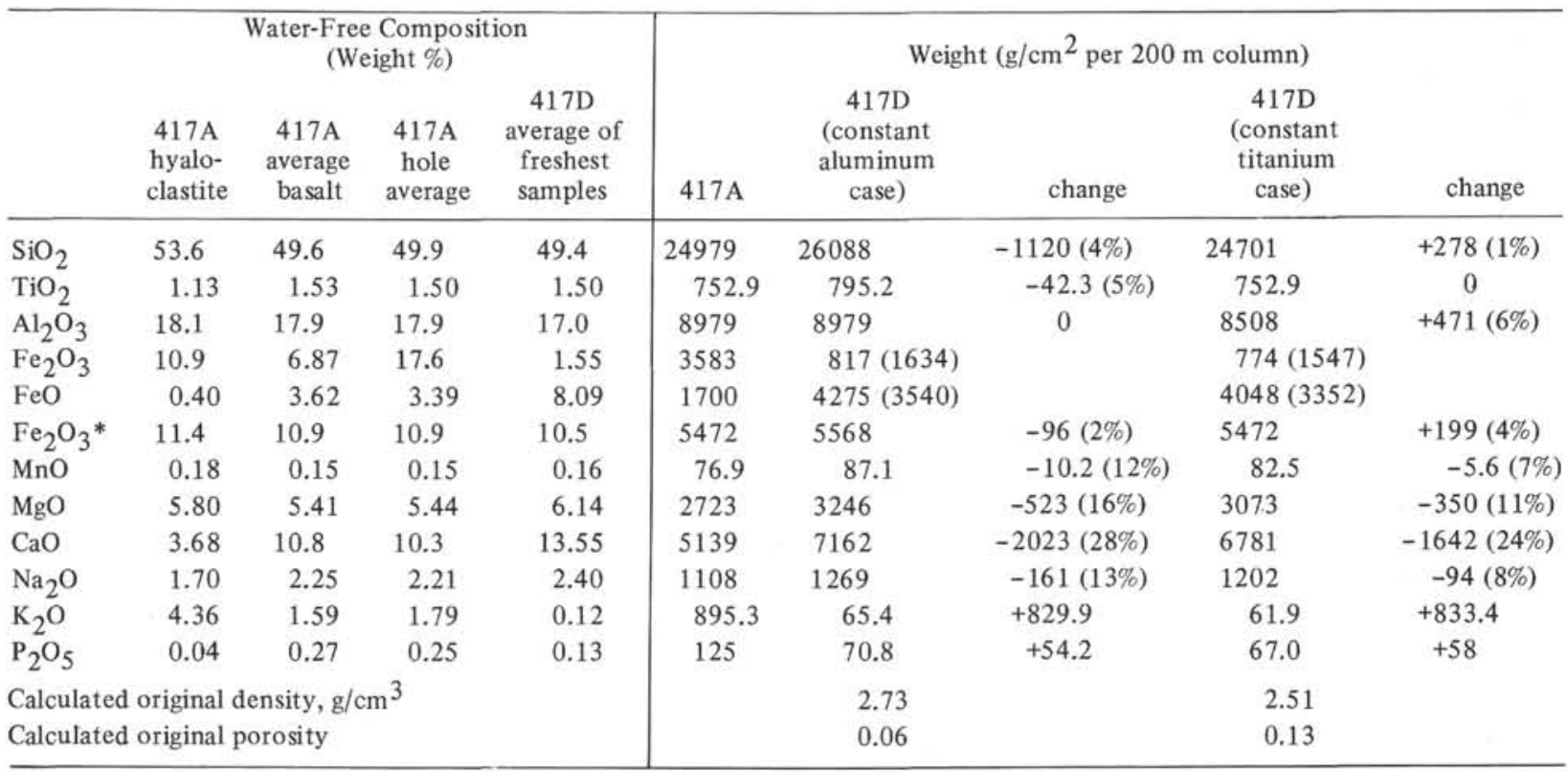

Note: Data shown are the average water-free compositions for hyaloclastite, basalt, and the total for Hole 417A; and the total weight of each oxide in Hole $417 \mathrm{~A}$, assuming a 200 -meter column $1 \mathrm{~cm}^{2}$ in cross-section. These are calculated on a core-by-core basis, using average densities and compositions for each core. The average composition of the 11 freshest Hole 417D samples is also given. Assuming that the Hole $417 \mathrm{~A}$ rocks were originally the same in composition as those in Hole 417D, the calculated weight of each oxide prior to alteration and the change in weight are presented for the constant aluminum and constant titanium cases for Hole 417A. The original calculated density and porosity (the latter assuming an original rock density of $2.9 \mathrm{~g} / \mathrm{cm}^{2}$ ) are also given.
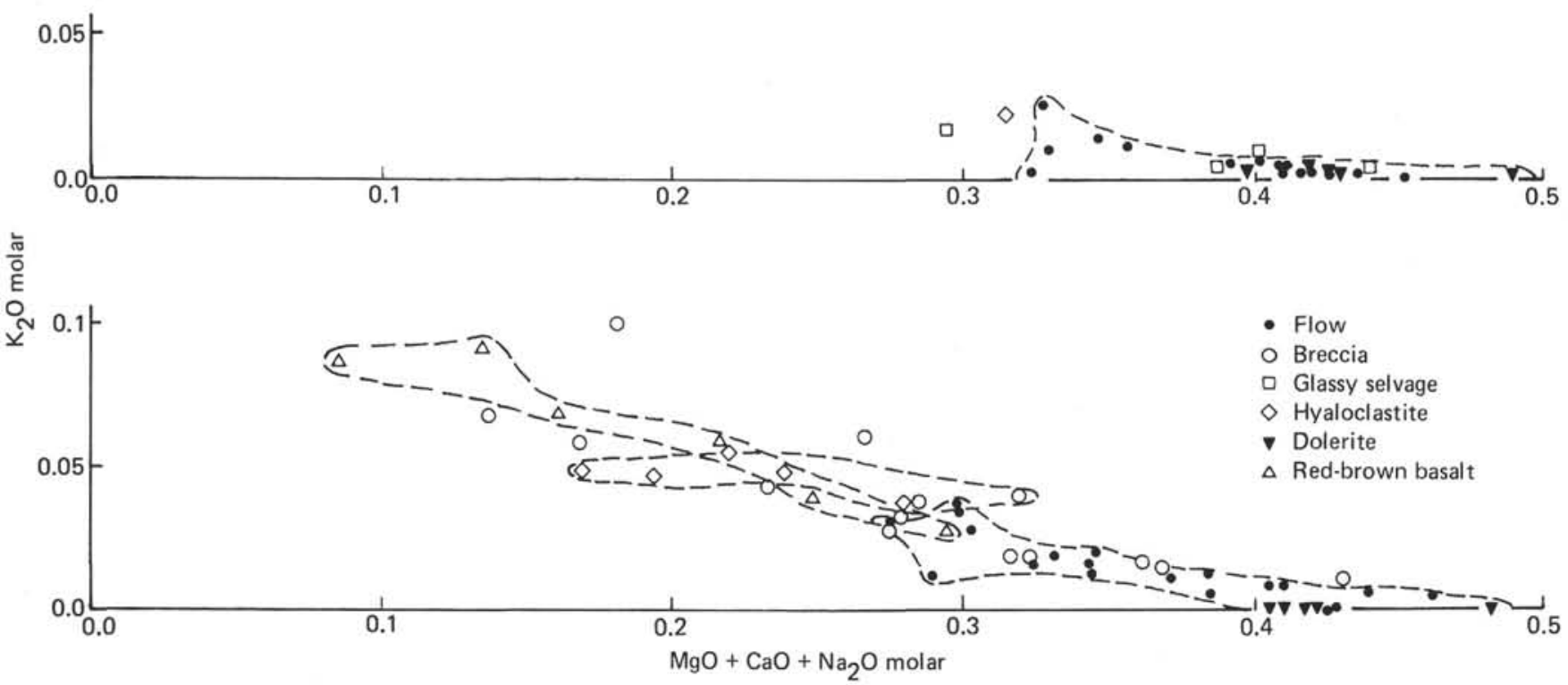

Figure 7. $\mathrm{K}_{2} \mathrm{O}$ versus $\mathrm{MgO}+\mathrm{Ca}^{+}+\mathrm{Na}_{2} \mathrm{O}$ in Holes $417 \mathrm{~A}$ and $417 \mathrm{D}$. Units are moles per 100 grams. Symbols as in Figure 2.

\section{CONCLUSIONS}

Hole $417 \mathrm{~A}$ is an example of extreme low-temperature weathering and quantitatively demonstrates the importance of this process. Potassium is absorbed in prodigious amounts, and calcium, magnesium, and sodium are all released. The process consumes acid (hydrogen ion from bicarbonate) and releases oxygen, even apparently in excess of what is required to oxidize the iron, although probably in the form of $\mathrm{H}_{2} \mathrm{O}$. The amount of water required is vast and the mechanism of driving the water through the rock would appear to have to be thermal, i.e., convection caused by heat loss in a young, cooling oceanic crust. Topographic highs which remain uncovered by sediment for millions of 
TABLE 3B

Chemicai Budget of Alteration in Hole 417A

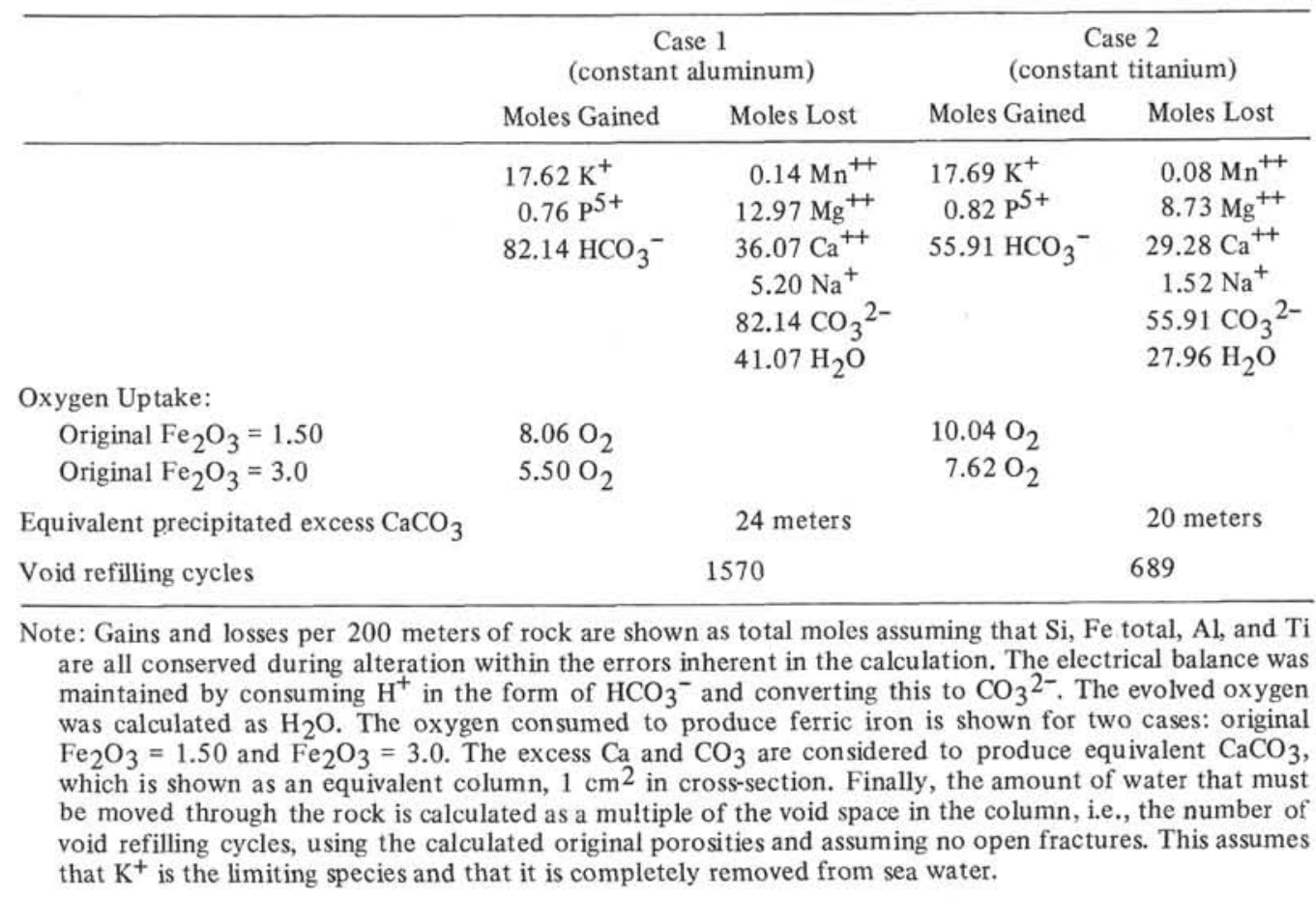

years may serve as the preferred sites for channeled effluence of this water, which recharges over a vast area at a very slow rate.

The further implications of these results depend on the relative abundance in the world ocean of sites such as Hole $417 \mathrm{~A}$. If topographically high sites which become channels for effluent water amount to a few per cent of the ocean floor, then they could easily account for the excess potassium being added to the world ocean (Maynard, 1976). Finally, although many dredged hydrothermally altered pillow basalts appear to be magnesium-enriched, the relative abundance of magnesium-depleted crustal materials needs to be established in order to determine whether the crust is adding or subtracting magnesium from the world ocean.

\section{ACKNOWLEDGMENTS}

Discussions with Paul Robinson, James Lawrence, and Karlis Muehlenbachs have been most valuable. Mike Mottl and Bill Bryan critically reviewed the paper. Chemical analyses were performed by Max Budd, Department of Geological Sciences, State University of New York, Binghamton, and by D.C. Bankston and M. Sulanowska at the Woods Hole Oceanographic Institution. NSF Grant GA-22971 is gratefully acknowledged.

\section{REFERENCES}

Bischoff, J. and Dickson, F.W., 1975. Seawater-basalt interaction at $200^{\circ} \mathrm{C}$ and 500 bars: implications as to the origin of sea floor heavy metal deposits and regulation of seawater chemistry, Earth Planet. Sci. Lett., v. 25, p. 385-397.

Donnelly, T.W. and Wallace, J.L., 1976. Major and minor element chemistry of Antarctic clay-rich sediments: Sites 322, 323 and 325, DSDP Leg 35. In Hollister, C.D., Craddock, C., et al., Initial Reports of the Deep Sea Drilling Project, v. 35: Washington (U.S. Government Printing Office), p.427-446.

Donnelly, T.W., Melson, W., Kay, R., and Rogers, J.J.W., 1973. Basalts and dolerites of Late Cretaceous age from the central Caribbean. In Edgars, N.T., Saunders, J.B., et al.,
Initial Reports of the Deep Sea Drilling Project, v. 15: Washington (U.S. Government Printing Office), p. 1023-1030.

Hart, R., 1970. Chemical exchange between seawater and deep ocean basalts, Earth Planet. Sci. Lett., v.9, p. 269-279.

Humphris, S.E. and Thompson, G., 1978. Hydrothermal alteration of oceanic basalts by seawater, Geochim. Cosmochim Acta, v. 42 , p. $107-125$.

Matthews, B.M., 1971. Altered basalts from Swallow Bank, an abyssal hill in the N.E. Atlantic and from a nearby seamount, Phil. Trans. Roy. Soc. London, v. 268, p. 551-571.

Maynard, J.B., 1976. The long-term buffering of the oceans, Geochim. Cosmochim. Acta, v. 40, p. 1523-1532.

Mottl, M.J., 1976. Chemical exchange between seawater and basalt during hydrothermal alteration of the oceanic crust, Ph.D. Thesis, Harvard University.

Mottl, M.J. and Holland, H.D., in press. Chemical exchange during hydrothermal alteration of basalt by seawater. 1. Experimental results for major and minor components of seawater and $\mathrm{Ba}$, Geochim. Cosmochim. Acta.

Robinson, P.T., Flower, M.F.J., Schmincke, H.-U., and Ohnmacht, W., 1977. Low temperature alteration of oceanic basalts, DSDP Leg 37. In Aumento, F., Melson, W.G., et al., Initial Reports of the Deep Sea Drilling Project, v.37: Washington (U.S. Government Printing Office), p. 775-794.

Scott, R.B. and Hajash, A., Jr., 1976. Initial submarine alteration of basaltic pillow lavas: a microprobe study, Am. J. Sci., v. 276, p. 480-501.

Thompson, G., 1973. A geochemical study of the low temperature interaction of seawater and oceanic igneous rocks, EOS, Trans. Am. Geophys. Union, v. 54, p. 1015-1019.

Thompson, G. and Bankston, D.C., 1969. A technique for trace element analysis of powdered materials using the d.c. arc and photoelectric spectrometry, Spectrochim. Acta, v. 24B, p. $335-350$.

Thompson, G. and Humphris, S., 1977. Seawater-rock interactions in the oceanic basement, In Pacquet, H. and Tardy, Y., (Eds.), Second Internat. Symp. on water-rock interaction, Proc., v.III, Science Geologique, Univ. Louis Pasteur, Strasbourg, France, p.3-8. 